\title{
Elioraea tepidiphila gen. nov., sp. nov., a slightly thermophilic member of the Alphaproteobacteria
}

Correspondence Milton S. da Costa milton@ci.uc.pt

\author{
Luciana Albuquerque, ${ }^{1}$ Fred A. Rainey, ${ }^{2}$ M. Fernanda Nobre ${ }^{1}$ \\ and Milton S. da Costa ${ }^{3}$
}

\author{
${ }^{1}$ Department of Zoology and Center for Neurosciences and Cell Biology, University of Coimbra, \\ 3004-517 Coimbra, Portugal \\ ${ }^{2}$ Department of Biological Sciences, Louisiana State University, Baton Rouge, LA 70803, USA \\ ${ }^{3}$ Department of Biochemistry, University of Coimbra, 3001-401 Coimbra, Portugal
}

\begin{abstract}
A bacterial isolate, strain $\mathrm{TU}-7^{\top}$, with an optimum growth temperature of about $45-50{ }^{\circ} \mathrm{C}$ and an optimum $\mathrm{pH}$ for growth between 8.0 and 8.5, was recovered from a hot spring in the Furnas area of the island of São Miguel in the Azores. The new isolate is non-pigmented, facultatively chemolithoorganotrophic, strictly aerobic and catalase- and oxidase-positive. The organism oxidized thiosulfate to sulfate with enhancement of growth. This organism assimilated organic acids but did not assimilate carbohydrates or polyols. 16S rRNA gene sequence analysis placed strain TU- $7^{\top}$ within the radiation of the Alphaproteobacteria as a deep branch of the family Acetobacteriaceae. The major fatty acids of strain TU-7 ${ }^{\top}$ are $18: 1 \omega 7 c, 18: 0,19: 0$ cyclo $\omega 8 c$ and an aliphatic chain with an equivalent chain-length of 20.195 , identified as $19: 02-\mathrm{OH}$ cyclo $\omega 8(\Delta 11: 12)$. Ubiquinone 10 is the major respiratory quinone and the major polar lipids are phosphatidylcholine, phosphatidylethanolamine, diphosphosphatidylglycerol and phosphatidylglycerol in addition to two unidentified aminolipids. Bacteriochlorophyll a and puf genes were not detected. Based on 16S rRNA gene sequence analysis and physiological and biochemical characteristics, we describe a novel species of a new genus represented by strain $\mathrm{TU}-7^{\top}$, for which we propose the name Elioraea tepidiphila gen. nov., sp. nov. The type strain of Elioraea tepidiphila is strain TU-7 ${ }^{\top}\left(=\mathrm{DSM} 17972^{\top}=\mathrm{CIP} 109115^{\top}\right)$.
\end{abstract}

The Alphaproteobacteria comprises many species with diverse characteristics; some organisms are strictly organotrophic or facultative chemolithoorganotrophic, while others are chemolithoautotrophic. A large number of organisms possess bacteriochlorophyll (BChl) $a$, and some have been shown to be photoautotrophic. However, only a few species isolated from hot springs, such as Rubritepida flocculans (Alarico et al., 2002), Porphyrobacter tepidarius (Hanada et al., 1997), Porphyrobacter cryptus (Rainey et al., 2003) and Albidovulum inexpectatum (Albuquerque et al., 2002), have optimum growth temperatures of around $50{ }^{\circ} \mathrm{C}$, but do not grow at $55{ }^{\circ} \mathrm{C}$. With the exception of Albidovulum inexpectatum, which is closely related to the species of the genus Rhodovulum and appears to have lost phototrophic metabolism, all other slightly thermophilic alphaproteobacteria reported to date are red-pigmented and contain BChl $a$.

\section{Abbreviation: BChl, bacteriochlorophyll.}

The GenBank/EMBL/DDBJ accession number for the 16S rRNA gene sequence of strain TU-7 ${ }^{\top}$ is EF519867.

Results of one-dimensional TLC of polar lipids and analysis of the fatty acid composition of strain TU-7 ${ }^{\top}$ are available as supplementary material with the online version of this paper.
We recently isolated a slightly thermophilic, non-pigmented organism, designated $\mathrm{TU}-\mathrm{7}^{\mathrm{T}}$, from a hot spring on the island of São Miguel in the Azores, which, on the basis of phenotypic characteristics and phylogenetic position, we believe to represent a novel species of a new genus.

Strain TU-7 ${ }^{\mathrm{T}}$ was isolated from a hot spring in the Furnas area of S. Miguel. Water samples were maintained without temperature control for 6 days and then filtered through membrane filters (Gelman type GN-6; pore size $0.45 \mu \mathrm{m}$, diameter $47 \mathrm{~mm}$ ). The filters were placed on the surface of solidified Thermus medium (Williams \& da Costa, 1992), wrapped in plastic bags and incubated at $50{ }^{\circ} \mathrm{C}$ for up to 4 days. Cultures were purified by subculturing and the isolates were stored at $-70{ }^{\circ} \mathrm{C}$ in Thermus medium with $15 \%$ $(\mathrm{w} / \mathrm{v})$ glycerol. Culture in R3A medium (Reasoner \& Geldreich, 1985) was later adopted because it resulted in higher growth yields. Rubritepida flocculans $\mathrm{H}-8^{\mathrm{T}}$, Rhodovulum sulfidophilum DSM $1374^{\mathrm{T}}$ and Albidovulum inexpectatum FRR $-10^{\mathrm{T}}$ were used for comparative purposes.

Cell morphology and motility were examined by phasecontrast microscopy during the exponential growth phase. Flagella were visualized by light microscopy after staining 
of the cells with the Ryu stain (Heimbrook et al., 1989). Unless otherwise stated, all biochemical and tolerance tests were performed, as described previously (Pires et al., 2005), in R3A liquid medium without starch and glucose or on R3A agar without starch and glucose at $50{ }^{\circ} \mathrm{C}$ for up 6 days. The growth temperature range of the strains was examined at 25 , $30,35,45,50$ and $55{ }^{\circ} \mathrm{C}$ by measuring the turbidity $(610 \mathrm{~nm})$ of cultures incubated in $300 \mathrm{ml}$ metal-capped Erlenmeyer flasks, containing $100 \mathrm{ml}$ medium in a rotary water-bath shaker at 150 r.p.m. (Albuquerque et al., 2005). The $\mathrm{pH}$ range for growth was examined at $50{ }^{\circ} \mathrm{C}$ in the same medium by using $50 \mathrm{mM}$ MES, HEPES, TAPS or CAPSO over a $\mathrm{pH}$ range from 5.5 to 10.5 in a rotary water-bath shaker (Albuquerque et al., 2005). Catalase, oxidase and DNase activities were examined as described previously (Pires et al., 2005). Additional enzyme activities were assessed using the API ZYM system (bioMérieux) at $50{ }^{\circ} \mathrm{C}$. Anaerobic growth was assessed in cultures in R3A medium without starch and glucose, containing $\mathrm{KNO}_{3}\left(1.0 \mathrm{~g} \mathrm{l}^{-1}\right)$ incubated in anaerobic chambers (GENbox anaer; bioMérieux). Single-carbon source assimilation tests were performed in a minimal medium composed of Degryse basal salts (Degryse et al., $1978)$ to which filter-sterilized ammonium sulfate $\left(0.5 \mathrm{gl}^{-1}\right)$, yeast extract $\left(0.1 \mathrm{~g} \mathrm{l}^{-1}\right)$ and the carbon source $\left(2.0 \mathrm{~g} \mathrm{l}^{-1}\right)$ were added. Growth of strains on single carbon sources was examined by measuring the turbidity of cultures incubated at $50{ }^{\circ} \mathrm{C}$ in $20 \mathrm{ml}$ screw-capped tubes containing $10 \mathrm{ml}$ medium for up to 6 days. Acid production from carbohydrates was determined by using the API $50 \mathrm{CH}$ system (bioMérieux) according to the manufacturer's instructions using API $50 \mathrm{CHB} / \mathrm{E}$ medium. Results were recorded after 24 and $48 \mathrm{~h}$ and 5 days of incubation at $50{ }^{\circ} \mathrm{C}$.

Autotrophic growth of the organism on $\mathrm{H}_{2}$, sodium thiosulfate $\left(1.0 \mathrm{~g} \mathrm{l}^{-1}\right)$, sodium tetrathionate $\left(1.0 \mathrm{~g} \mathrm{l}^{-1}\right)$, sodium sulfite $\left(1.0 \mathrm{~g} \mathrm{l}^{-1}\right)$ and sodium sulfide $\left(0.5 \mathrm{~g} \mathrm{l}^{-1}\right)$ was investigated in DSMZ medium 27 lacking ethanol, vitamin $\mathrm{B}_{12}$, sodium sulfide or organic substrates, with $0.1 \mathrm{~g}$ yeast extract $\mathrm{l}^{-1}$ (http://www.dsmz.de/media/med027.htm) in the dark under aerobic conditions; cultures to assess autotrophic growth on $\mathrm{H}_{2}$ were placed in sealed chambers to which this gas was added. Cultures containing $0.1 \mathrm{~g}$ yeast extract $\mathrm{l}^{-1}$ without $\mathrm{H}_{2}$ or any of the reduced sulfur compounds were used as controls.

Phototrophic growth was assessed in DSMZ medium 27 (lacking ethanol and vitamin $B_{12}$ ) supplemented with neutralized sodium sulfide solution $\left(0.1 \mathrm{~g} \mathrm{l}^{-1}\right)$ or with sodium thiosulfate $\left(0.1 \mathrm{~g} \mathrm{l}^{-1}\right)$ in completely filled screwcapped bottles under incandescent illumination $(1000 \mathrm{~lx})$ along with $R d v$. sulfidophilum DSM $1374^{\mathrm{T}}$ as a control.

Chemolithoorganotrophic growth on sodium thiosulfate was assessed under aerobic conditions at the optimum growth temperature in DSMZ medium 27 lacking sulfate and containing yeast extract $\left(0.3 \mathrm{~g} \mathrm{l}^{-1}\right)$, sodium succinate $\left(1.0 \mathrm{~g} \mathrm{l}^{-1}\right)$ and sodium acetate $\left(0.5 \mathrm{~g} \mathrm{l}^{-1}\right)$. Filter-sterilized sodium thiosulfate was added to the medium at concentrations that varied between 0.5 and $5.0 \mathrm{~g} \mathrm{l}^{-1}$. At appropriate intervals, the turbidity of the cultures was determined and the cells were harvested and centrifuged. Levels of thiosulfate and sulfate in the supernatants were determined using the methods described by Westley (1987) and Sörbo (1987), respectively.

Cultures for polar lipid analysis were grown in 11 Erlenmeyer flasks containing $250 \mathrm{ml}$ medium at $50{ }^{\circ} \mathrm{C}$ in a rotary water-bath shaker until the late exponential phase. Harvesting of cultures, extraction of lipids and onedimensional TLC were performed as described previously (Moreira et al., 2000). Lipoquinones were extracted, purified by TLC and separated by HPLC (Tindall, 1989). Cultures for fatty acid analysis were grown on solidified R3A medium without starch and glucose, in sealed plastic bags submerged in a water bath at $50{ }^{\circ} \mathrm{C}$ for $48 \mathrm{~h}$. Fatty acid methyl esters (FAMEs) were obtained from fresh wet biomass and separated, identified and quantified with the standard MIS Library Generation Software (Microbial ID, Inc.) as described previously (Albuquerque et al., 2005).

Cultures for carotenoid analysis were harvested during the exponential phase of growth and washed twice by centrifugation with MOPS buffer (MOPS/ $\mathrm{NaOH}, 0.01 \mathrm{M} ; \mathrm{KCl}$, $0.1 \mathrm{M} ; \mathrm{MgCl}_{2}, 0.001 \mathrm{M} ; \mathrm{pH}$ 7.5). Carotenoids were extracted with chloroform/methanol $(1: 2, \mathrm{v} / \mathrm{v})$ in the dark to avoid photo-oxidation of the pigments (Liaaen-Jensen \& Jensen, 1971). One-dimensional TLC was performed on silica gel G plates (Merck no. 5626) using a solvent system composed of chloroform/methanol $(95: 12.5, \mathrm{v} / \mathrm{v})$. Bacteriochlorophylls were extracted with acetone/methanol $(7: 2, \mathrm{v} / \mathrm{v})$ and the absorption spectrum of the extract was examined on a UVIKON spectrophotometer 942 .

The isolation of DNA from strain $\mathrm{TU}-\mathrm{7}^{\mathrm{T}}$ and $R u t$. flocculans $\mathrm{H}-8^{\mathrm{T}}$ was performed as described by Marmur (1961). PCR amplification of puf genes was performed with a pair of degenerate primers (Alarico et al., 2002), based on conserved regions from homologous genes in related organisms and used to amplify a continuous nucleotide stretch corresponding to a $1.5 \mathrm{~kb}$ fragment that included pufL and pufM. A PCR product was visualized by agarose gel electrophoresis, purified from agarose with a Wizard SV Gel DNA kit (Promega) and ligated in the pGEM T-Easy vector (Promega). Transformation of Escherichia coli XL1Blue was carried out with standard procedures described in Sambrook et al. (1989). After confirmation of positive clones, cells were grown overnight in ampicillin-containing $\left(50 \mu \mathrm{g} \mathrm{ml}^{-1}\right)$ LB medium and plasmids were isolated (High Pure plasmid isolation kit; Roche). The inserts were sequenced by Agowa GmbH (Berlin, Germany).

DNA for determination of the $\mathrm{G}+\mathrm{C}$ content was isolated as described previously (Nielsen et al., 1995). The G+C content of DNA was determined by HPLC as described by Mesbah et al. (1989).

Extraction of genomic DNA for 16S rRNA gene sequence determination, PCR amplification of the 16S rRNA gene and sequencing of the purified PCR products were carried 
out as described previously (Rainey et al., 1996). Purified reactions were electrophoresed using a model 310 Genetic Analyzer (Applied Biosystems). The 16S rRNA gene sequence was aligned against representative reference sequences of members of the Proteobacteria using the ae 2 editor (Cole et al., 2003). The method of Jukes \& Cantor (1969) was used to calculate evolutionary distances. Phylogenetic dendrograms and bootstrap analyses were generated using various algorithms contained in the PHYLIP package (Felsenstein, 1993).

Strain $\mathrm{TU}-7^{\mathrm{T}}$ was isolated from a hot spring with a temperature of $70{ }^{\circ} \mathrm{C}$ and $\mathrm{pH}$ of 7.5. Only strain $\mathrm{TU}-7^{\mathrm{T}}$ was recovered from one plate containing 21 colonies. The other organisms isolated from the same sample included strains of Truepera radiovictrix, Meiothermus timidus and Tepidicella xavieri (Albuquerque et al., 2005; Pires et al., 2005; França et al., 2006). Phylogenetic analysis of a nearly complete $16 \mathrm{~S}$ rRNA gene sequence showed strain TU-7 $7^{\mathrm{T}}$ to represent a distinct lineage within the Alphaproteobacteria (Fig. 1). Strain TU $-7^{\mathrm{T}}$ clustered with an environmental clone sequence designated CCSD_DF730_B11, with which it shared $99.7 \%$ pairwise sequence similarity (Fig. 1). $16 \mathrm{~S}$ rRNA gene sequence similarity values between strain TU$7^{\mathrm{T}}$ and cultured representatives of the closest relatives were in the range $88.3-91.8 \%$. Phylogenetic analysis using the neighbour-joining, maximum-likelihood and parsimony methods showed the position of strain TU-7 ${ }^{\mathrm{T}}$ at the root of the family Acetobacteriaceae supported by $100 \%$ bootstrap values. Based on $16 \mathrm{~S}$ rRNA gene sequence similarity, the closest named relative of strain $\mathrm{TU}-7^{\mathrm{T}}$ is Acidisphaera rubrifaciens. This relationship is reflected in the short branch of this species, but indicates no close relationship between strain TU- $7^{\mathrm{T}}$ and Acidisphaera rubrifaciens. Based on its deep branching position, the novel organism could be considered to represent a new family, but it would be better to obtain additional isolates before proposing a new family for this lineage. The $\mathrm{G}+\mathrm{C}$ content of the DNA of strain TU-7 ${ }^{\mathrm{T}}$ was $70.9 \pm 0.6 \mathrm{~mol} \%$.

Strain TU-7 ${ }^{\mathrm{T}}$ formed very short, Gram-negative, rod-shaped cells $(0.5-1.0 \mu \mathrm{m}$ wide and $1.0-1.5 \mu \mathrm{m}$ long) that were motile by means of single polar flagella. Colonies were translucent and non-pigmented on R3A agar without starch and glucose. The organisms had an optimum growth temperature between 45 and $50{ }^{\circ} \mathrm{C}$ and did not grow at 25 or $55^{\circ} \mathrm{C}$. The optimum $\mathrm{pH}$ for growth of strain $\mathrm{TU}-7^{\mathrm{T}}$ was $\mathrm{pH} 8.0-8.5$, and no growth was detected at $\mathrm{pH} 5.5$ or 10.0. The organism was oxidase- and catalase-positive and hydrolysed hippurate, starch and xylan weakly. Aesculin, arbutin, gelatin, casein and elastin were not hydrolysed. Strain TU-7 ${ }^{\mathrm{T}}$ used organic acids as single carbon and energy sources, but was unable to utilize any of the carbohydrates or polyols examined. Weak growth was observed with proline and glutamine. Yeast extract was necessary for growth in minimal medium. Nitrate was reduced to nitrite but anaerobic growth with nitrate as an electron acceptor was not observed. The organism produced acid from D-ribose, D-fructose, L-sorbose, D-tagatose and potassium 5-ketogluconate.

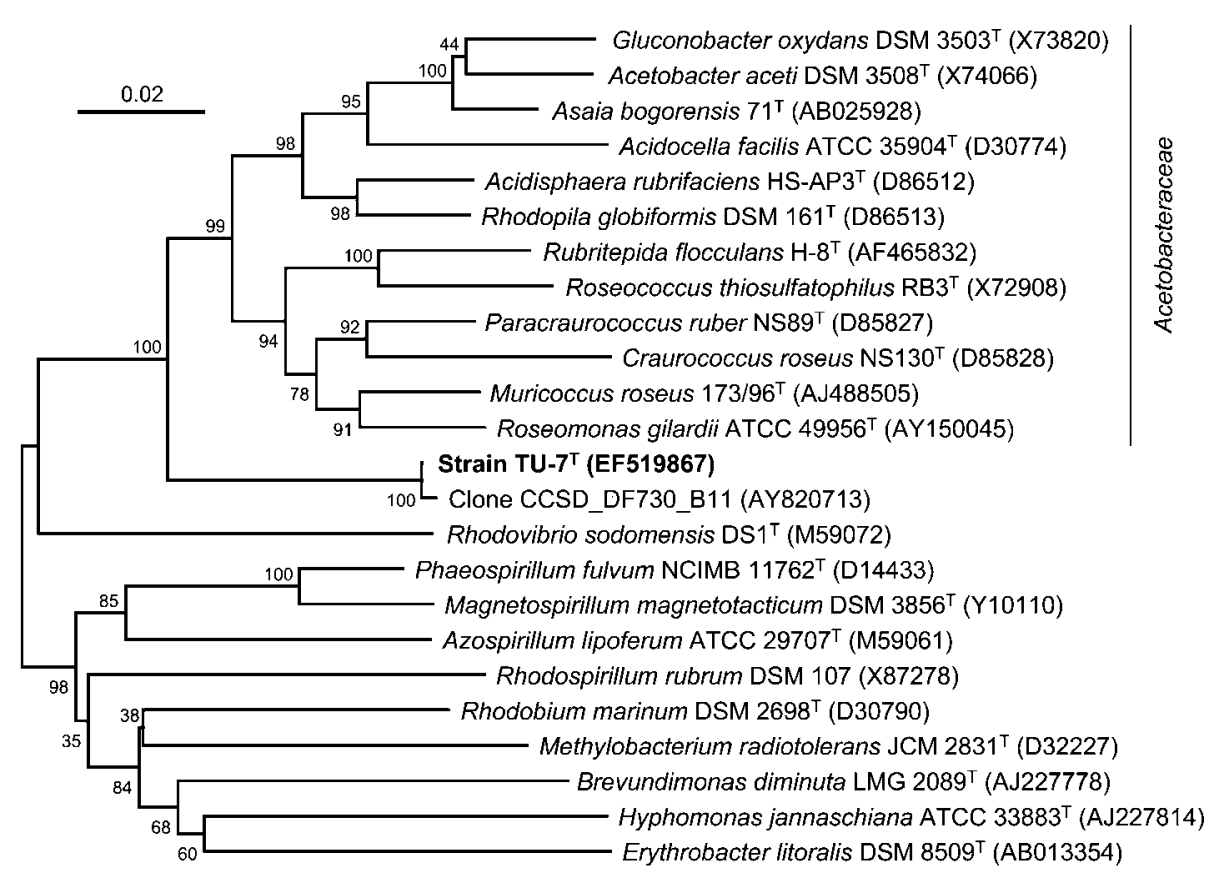

Fig. 1. $16 \mathrm{~S}$ rRNA gene sequence-based phylogenetic dendrogram showing the relationships of strain $\mathrm{TU}-7^{\top}$ and related taxa. The dendrogram was constructed from distance matrices using the neighbour-joining method. Numbers at branching points represent bootstrap percentages from 1000 data samplings. Bar, 2 inferred substitutions per 100 nucleotides. 
The addition of thiosulfate to DSMZ medium 27 containing yeast extract, succinate and acetate led to an increase in the biomass of strain $\mathrm{TU}-7^{\mathrm{T}}$, indicating that thiosulfate was used as an energy source in the presence of organic substrates (results not shown). Determination of the levels of sulfate and thiosulfate in the medium during growth indicated that thiosulfate was oxidized completely to sulfate (results not shown). Photoautotrophic growth and chemolithotrophic growth with $\mathrm{H}_{2}$, thiosulfate, tetrathionate, sulfite or sulfide were not observed.

In contrast to the type strain of $R d v$. sulfidophilum, we did not detect the presence of BChl $a$ in strain TU-7 $7^{\mathrm{T}}$ under aerobic or anaerobic growth conditions. Carotenoid pigments were not detected in extracts under any experimental conditions. The presence of pufL and $p u f M$ genes was not detected by PCR amplification in strain TU-7 ${ }^{\mathrm{T}}$.

The polar lipid pattern on TLC revealed the presence of phosphatidylcholine, phosphatidylethanolamine, diphosphosphatidylglycerol and phosphatidylglycerol in addition to two unidentified aminolipids (Supplementary Fig. S1, available in IJSEM Online). The major respiratory lipoquinone was ubiquinone 10 . The fatty acid composition of strain $\mathrm{TU}-\mathrm{7}^{\mathrm{T}}$ was dominated by $18: 1 \omega 7 c, 18: 0$, 19:0 cyclo $\omega 8 c$ and a rare fatty acid with an equivalent chain-length (ECL) of 20.195, tentatively identified as 19:0 2-OH cyclo $\omega 8(\Delta 11: 12)$ (Supplementary Table S1).

Unexpectedly, strain TU-7 ${ }^{\mathrm{T}}$ was not able to assimilate any of the carbohydrates examined, even though acid was produced from a few sugars in the API $50 \mathrm{CH}$ system. The polar lipids and respiratory quinone were as one would expect for members of the Alphaproteobacteria. High levels of a rare fatty acid with an ECL of 20.195, identified as 19:0 2-OH cyclo $\omega 8(\Delta 11: 12)$ (Ralf Paisley, Microbial ID, Inc., personal communication), were found in this organism. This fatty acid, along with the less rare 19:0 cyclo $\omega 8 c$, have been found previously in the slightly thermophilic alphaproteobacterium Rut. flocculans, but not in the phylogenetically closely related organisms Roseococcus thiosulfatophilus, Craurococcus roseus and Paracraurococcus ruber (Alarico et al., 2002) (Table 1).

The fact that the 16S rRNA gene sequence of strain TU-7 ${ }^{\mathrm{T}}$ shows high similarity (99.7\%) to an environmental clone sequence designated CCSD_DF730_B11, which was recovered from drilling fluid (Zhang et al., 2005), is interesting from an ecological and diversity standpoint. The environmental clone sequence was recovered from drilling fluid at $730 \mathrm{~m}$, where the in situ temperature was $43{ }^{\circ} \mathrm{C}$, which is close to the optimum growth temperature of strain TU-7 $7^{\mathrm{T}}$. With such high $16 \mathrm{~S}$ rRNA gene sequence similarity, it could be considered that clone CCSD_DF730_B11 represents a strain or species of the novel genus to which strain TU-7 $7^{\mathrm{T}}$ is assigned. Based on the phylogenetic analysis and the phenotypic characteristics, which are distinct from those of members of the family Acetobacteriaceae (Table 1), we are of the opinion that the organism designated TU- $7^{\mathrm{T}}$ represents a new genus and species of the Alphaproteobacteria.

\section{Description of Elioraea gen. nov.}

Elioraea (E.li.o'ra.e.a. N.L. fem. n. Elioraea named in honour of Israeli microbiologist Eliora Z. Ron).

Form motile, rod-shaped cells that stain Gram-negative. Endospores are not formed. Facultatively chemolithoorganotrophic, strictly aerobic, oxidase- and catalase-positive. $\mathrm{BChl} a$ is not present. Major fatty acids are straight-chain saturated and unsaturated fatty acids including hydroxy derivatives; major phospholipids are phosphatidylcholine, phosphatidylethanolamine, diphosphosphatidylglycerol and phosphatidylglycerol; ubiquinone 10 is the major respiratory quinone. Thiosulfate is oxidized to sulfate. Organic compounds serve as carbon and energy sources. The genus Elioraea belongs to the Alphaproteobacteria. The type species is Elioraea tepidiphila.

\section{Description of Elioraea tepidiphila sp. nov.}

Elioraea tepidiphila (te.pi.di.phi'la. L. adj. tepidus warm; Gr. adj. philos loving; N.L. fem. adj. tepidiphila loving warmth).

Displays the following properties in addition to those described for the genus. Cells are 1.0-1.5 $\mu \mathrm{m}$ long and $0.5-$ $1.0 \mu \mathrm{m}$ wide. Colonies on R3A medium without starch and glucose are not pigmented. Slightly thermophilic; the optimum growth temperature is about $45-50{ }^{\circ} \mathrm{C}$ and growth does not occur at 25 or $55{ }^{\circ} \mathrm{C}$. The optimum $\mathrm{pH}$ is between 8.0 and 8.5; growth does not occur at pH 5.5 or 10.0. Grows in media with up to $1.5 \% \mathrm{NaCl}$. Yeast extract is required for growth. Nitrate is reduced to nitrite. Major fatty acids are $18: 0(24.8 \%), 18: 1 \omega 7 c(19.0 \%), 19: 02-\mathrm{OH}$ cyclo $\omega 8$ $(\Delta 11: 12)(18.6 \%), 19: 0$ cyclo $\omega 8 c(12.4 \%), 18: 1 \omega 7 c 11$ methyl (8.0 \%), 16:0 (5.4\%) and 18:0 3-OH (3.8\%). Starch, xylan and hippurate are degraded; aesculin, arbutin, gelatin, casein and elastin are not degraded. DNase-positive. Alkaline phosphatase, esterase (C4), esterase lipase (C8), leucine arylamidase, valine arylamidase, acid phosphatase and naphthol-AS-BI-phosphohydrolase test positive in API ZYM; other activities test negative. Succinate, $\alpha$-ketoglutarate, lactate, malate, pyruvate, glutamate, fumarate, gluconate, citrate, proline and glutamine are assimilated; glucose, mannose, galactose, fructose, sorbose, D- and L-arabinose, ribose, xylose, sucrose, maltose, lactose, trehalose, cellobiose, melibiose, melezitose, L-rhamnose, raffinose, L-fucose, ribitol, xylitol, sorbitol, erythritol, mannitol, myo-inositol, glycerol, acetate, aspartate, formate, glucuronate, alanine, asparagine, phenylalanine, glycine, histidine, isoleucine, leucine, lysine, methionine, arginine, serine, threonine, valine, ornithine and cysteine are not assimilated. Acid is produced from the following carbohydrates using API $50 \mathrm{CH}$ : ribose, fructose, $\mathrm{L}-$ sorbose, tagatose and potassium 5-ketogluconate. The G $+\mathrm{C}$ content of the DNA is $70.9 \pm 0.6 \mathrm{~mol} \%$.

The type strain, $\mathrm{TU}-7^{\mathrm{T}}\left(=\mathrm{DSM} 17972^{\mathrm{T}}=\mathrm{CIP} 109115^{\mathrm{T}}\right)$, was isolated from a hot spring at Furnas on the island of São Miguel in the Azores. 
Table 1. Characteristics that distinguish strain $\mathrm{TU}-7^{\top}$ and the genera Acetobacter, Acidocella, Craurococcus, Roseococcus and Rubritepida

Data for related genera were taken from Sievers \& Swings (2005) (Acetobacter), Hiraishi (2005) (Acidocella), Rathgeber \& Yurkov (2005) (Craurococcus), Alarico et al. (2002) (Craurococcus, Roseococcus and Rubritepida) and Yurkov (2005) (Roseococcus). -, Negative; +, positive; (+), weakly positive; ND, no data available.

\begin{tabular}{|c|c|c|c|c|c|c|}
\hline Characteristic & Strain $\mathrm{TU}-\mathrm{7}^{\mathrm{T}}$ & Acetobacter & Acidocella & Craurococcus & Roseococcus & Rubritepida \\
\hline Cell size $(\mu \mathrm{m})$ & $0.5-1.0 \times 1.0-1.5$ & $0.6-0.9 \times 1.0-4.0$ & $0.5-0.8 \times 1.0-2.0$ & $0.8-2.0$ & $0.9-1.3 \times 1.3-1.6$ & $0.7-1.2 \times 1.4-1.7$ \\
\hline Motility & + & + or - & + or - & - & + & + \\
\hline \multicolumn{7}{|l|}{ Growth temperature $\left({ }^{\circ} \mathrm{C}\right)$} \\
\hline Optimum & $45-50$ & $28-30$ & Mesophilic & $28-32$ & 30 & 50 \\
\hline \multicolumn{7}{|l|}{$\mathrm{pH}$ for growth } \\
\hline Range & $6.0-9.8$ & $3.0-9.0$ & $2.5-6.0$ & $7.2-8.0$ & ND & $6.5-9.5$ \\
\hline Optimum & $8.0-8.5$ & $4.0-6.0$ & Acidophilic & 7.5 & ND & $7.0-8.0$ \\
\hline \multicolumn{7}{|l|}{ Presence of: } \\
\hline BChl $a$ & - & - & - & + & + & + \\
\hline $19: 0$ cyclo $\omega 8 \mathrm{c}$ & + & ND & ND & - & - & + \\
\hline $\begin{array}{l}19: 02-\mathrm{OH} \text { cyclo } \omega 8 \\
(\Delta 11: 12)\end{array}$ & + & ND & ND & - & - & + \\
\hline $\begin{array}{l}\text { DNA G }+\mathrm{C} \text { content } \\
(\mathrm{mol} \%)\end{array}$ & 70.9 & $50.5-60.3$ & $58-65$ & 70.5 & 70.4 & 70.2 \\
\hline
\end{tabular}

${ }^{\star}$ Except Acetobacter peroxydans.

\section{Acknowledgements}

This work was supported by the Fundação para a Ciência e a Tecnologia (FCT), Portugal, and FEDER, project A005/2005, action V.5.1, and by the Governor's Biotechnology Initiative of the Louisiana Board of Regents (BOR\#021 - Moving an Established Marine Biotechnology Program to the Next Level: Natural Product Screening and Development). We also wish to thank Jean Euzéby (Toulouse, France) for the etymology of the name.

\section{References}

Alarico, S., Rainey, F. A., Empadinhas, N., Schumann, P., Nobre, M. F. \& da Costa, M. S. (2002). Rubritepida flocculans gen. nov., sp. nov., a new slightly thermophilic member of the $\alpha-1$ subclass of the Proteobacteria. Syst Appl Microbiol 25, 198-206.

Albuquerque, L., Santos, J., Travassos, P., Nobre, M. F., Rainey, F. A., Wait, R., Empadinhas, N., Silva, M. T. \& da Costa, M. S. (2002). Albidovulum inexpectatum gen. nov., sp. nov., a non-photosynthetic and slightly thermophilic bacterium from a marine hot spring that is very closely related to the photosynthetic genus Rhodovulum. Appl Environ Microbiol 68, 4266-4273.

Albuquerque, L., Simões, C., Nobre, M. F., Pino, N. M., Battista, J. R., Silva, M. T., Rainey, F. A. \& da Costa, M. S. (2005). Truepera radiovictrix gen. nov., sp. nov., a new radiation resistant species and the proposal of Trueperaceae fam. nov. FEMS Microbiol Lett 247, 161-169.

Cole, J. R., Chain, B., Marsh, T. L., Farris, R. J., Wang, Q., Kulam, S. A., Chandra, S., McGarrell, D. M., Schmidt, T. M. \& other authors (2003). The Ribosomal Database Project (RDP-II): previewing a new autoaligner that allows regular updates and the new prokaryotic taxonomy. Nucleic Acids Res 31, 442-443.

Degryse, E., Glansdorff, N. \& Pierard, A. (1978). A comparative analysis of extreme thermophilic bacteria belonging to the genus Thermus. Arch Microbiol 117, 189-196.

Felsenstein, J. (1993). PHYLIP (phylogeny inference package), version 3.5.1. Distributed by the author. Department of Genome Sciences, University of Washington, Seattle, USA.

França, L., Rainey, F. A., Nobre, M. F. \& da Costa, M. S. (2006). Tepidicella xavieri gen. nov., sp. nov., a betaproteobacterium isolated from a hot spring runoff. Int J Syst Evol Microbiol 56, 907-912.

Hanada, S., Kawase, Y., Hiraishi, A., Takaichi, S., Matsuura, K., Shimada, K. \& Nagashima, K. V. P. (1997). Porphyrobacter tepidarius sp. nov., a moderately thermophilic aerobic photosynthetic bacterium isolated from a hot spring. Int J Syst Bacteriol 47, 408-413.

Heimbrook, M. E., Wang, W. L. L. \& Campbell, G. (1989). Staining bacterial flagella easily. J Clin Microbiol 27, 2612-2615.

Hiraishi, A. (2005). Genus IV. Acidocella Kishimoto, Kosako, Wakao, Tano, and Hiraishi 1996, 362 ${ }^{\mathrm{VP}}$. In Bergey's Manual of Systematic 
Bacteriology, 2nd edn, vol. 2, part C, pp. 65-68. Edited by D. J. Brenner, N. R. Krieg, J. T. Staley \& G. M. Garrity. New York: Springer.

Jukes, T. H. \& Cantor, C. R. (1969). Evolution of protein molecules. In Mammalian Protein Metabolism, vol. 3, pp. 21-132. Edited by H. N. Munro. New York: Academic Press.

Liaaen-Jensen, S. \& Jensen, A. (1971). Quantitative determination of carotenoids in photosynthetic tissues. Methods Enzymol 23, 586-602.

Marmur, J. (1961). A procedure for the isolation of deoxyribonucleic acid from microorganisms. J Mol Biol 3, 208-218.

Mesbah, M., Premachandran, U. \& Whitman, W. B. (1989). Precise measurement of the $\mathrm{G}+\mathrm{C}$ content of deoxyribonucleic acid by highperformance liquid chromatography. Int J Syst Bacteriol 39, 159-167.

Moreira, C., Rainey, F. A., Nobre, M. F., Silva, M. T. \& da Costa, M. S. (2000). Tepidimonas ignava gen. nov., sp. nov., a new chemolithoheterotrophic and slightly thermophilic member of the $\beta$-Proteobacteria. Int $J$ Syst Evol Microbiol 50, 735-742.

Nielsen, P., Fritze, D. \& Priest, F. G. (1995). Phenetic diversity of alkaliphilic Bacillus strains: proposal for nine new species. Microbiology 141, 1745-1761.

Pires, A. L., Albuquerque, L., Tiago, I., Nobre, M. F., Empadinhas, N., Veríssimo, A. \& da Costa, M. (2005). Meiothermus timidus sp. nov., a slightly thermophilic yellow-pigmented species. FEMS Microbiol Lett 245, 39-45.

Rainey, F. A., Ward-Rainey, N., Kroppenstedt, R. M. \& Stackebrandt, E. (1996). The genus Nocardiopsis represents a phylogenetically coherent taxon and a distinct actinomycete lineage: proposal of Nocardiopsaceae fam. nov. Int J Syst Bacteriol 46, 1088-1092.

Rainey, F. A., Silva, J., Nobre, M. F., Silva, M. T. \& da Costa, M. S. (2003). Porphyrobacter cryptus sp. nov., a novel slightly thermophilic, aerobic, bacteriochlorophyll $a$-containing species. Int J Syst Evol Microbiol 53, 35-41.

Rathgeber, C. \& Yurkov, V. V. (2005). Genus VII. Craurococcus Saitoh, Suzuki and Nishimura 1998, 1044 ${ }^{\mathrm{VP}}$. In Bergey's Manual of Systematic
Bacteriology, 2nd edn, vol. 2, part C, pp. 70-72. Edited by D. J. Brenner, N. R. Krieg, J. T. Staley \& G. M. Garrity. New York: Springer.

Reasoner, D. J. \& Geldreich, E. E. (1985). A new medium for the enumeration and subculture of bacteria from potable water. Appl Environ Microbiol 49, 1-7.

Sambrook, J., Fritsch, E. F. \& Maniatis, T. (1989). Molecular Cloning: a Laboratory Manual, 2nd edn. Cold Spring Harbor, NY: Cold Spring Harbor Laboratory.

Sievers, M. \& Swings, J. (2005). Genus I. Acetobacter Beijerinck 1898, $215^{\mathrm{AL}}$. In Bergey's Manual of Systematic Bacteriology, 2nd edn, vol. 2, part C, pp. 51-54. Edited by D. J. Brenner, N. R. Krieg, J. T. Staley \& G. M. Garrity. New York: Springer.

Sörbo, B. (1987). Sulfate: turbidimetric and nephelometric methods. Methods Enzymol 143, 3-6.

Tindall, B. J. (1989). Fully saturated menaquinones in the archaebacterium Pyrobaculum islandicum. FEMS Microbiol Lett 60, 251-254.

Westley, J. (1987). Thiocyanate and thiosulfate. Methods Enzymol $143,23-25$.

Williams, R. A. D. \& da Costa, M. S. (1992). The genus Thermus and related microorganisms. In The Prokaryotes, 2nd edn, pp. 3745-3753. Edited by A. Balows, H. G. Trüper, M. Dworkin, W. Harder \& K. H. Schleifer. New York: Springer.

Yurkov, V. V. (2005). Genus XII. Roseococcus Yurkov, Stackebrandt, Holmes, Fuerst, Hugenholtz, Golecki, Gad'on, Gorlenko, Kompantseva and Drews 1994c, 430 VP. In Bergey's Manual of Systematic Bacteriology, 2nd edn, vol. 2, part C, pp. 85-87. Edited by D. J. Brenner, N. R. Krieg, J. T. Staley \& G. M. Garrity. New York: Springer.

Zhang, G., Dong, H., Xu, Z., Zhao, D. \& Zhang, C. (2005). Microbiol diversity in ultra-high-pressure rocks and fluids from the Chinese continental scientific drilling project in China. Appl Environ Microbiol 71, 3213-3227. 